\title{
The longevity of Anopheles sundaicus in a small area: Nongsa Pantai Villages, Batam City, Indonesia
}

\author{
Dewi Susanna ${ }^{1 *}$, Tris Eryando ${ }^{2}$ \\ From Challenges in malaria research \\ Basel, Switzerland. 10-12 October 2012
}

\section{Background}

Mosquito lifespan is one component of the lifetime transmission potential of an individual mosquito. The length of life or lifespan (longevity) of an adult Anopheles may affect its power of transmitting malaria [1]. This study was to analyze the longevity of Anopheles sundaicus in small area, Nongsa Patai Village, Batam City, Indonesia.

\section{Method}

Research used time trend design which investigated within 3-4 months (July-October) in Nongsa Pantai Sub-villages, Nongsa Pantai Village, Batam City, Indonesia. The estimation of An. sundaicus's longevity used a formula based on the Parous Rate and its gonothropic cycle, that is the duration of time the mosquito matures its eggs [2]. The gonothropic cycle of An. sundaicus is 3 days.

\section{Results}

The life span (longevity) of An. sundaicus in Nongsa Pantai Village ranged from 7.22 to 9.39 with 8.39 in average as shown in Table 1.
Anophelines go through four stages in their life cycle: egg, larva, pupa, and adult The first three stages are aquatic and last 5-14 days, depending on the species and the ambient temperature. The female Anopheles is not immediately infective after taking a blood meal and the parasite requires a period of time within the mosquito for its development to an infective stage. The period is termed the extrinsic incubation period [3]. A mosquito needs at least two feedings to complete one transmission cycle [4]. This parameter is strongly dependent on actual air average temperature. It may range from 8 days at $31^{\circ} \mathrm{C}$ to 22 days at $20^{\circ} \mathrm{C}$ (the mean value commonly used reaches 15 days). In Berlin, [5] probable extrinsic incubation time 21-24 days calculated for P. falciparum[2]. Theoretically, the time required for malaria transmission is at least 13-24 days under control of local temperature and humidity. That can be described as follows: 4-14 day for development from egg to pupae, and the extrinsic incubation period (EIP) ranged 8-10 days assuming the mosquito takes a blood meal directly from an infected person. The longevity of An. sundaicus in this area might transmit malaria when

Table 1 The estimation of longevity of An. sundaicus in Nongsa Pantai Village, Batam City, Riau Islands Province during July-October

\begin{tabular}{|c|c|c|c|c|}
\hline Observation (month) & Porous rate & Gonothropic cycle (days) & $p^{* *}$ & Longevity (days) \\
\hline July & 0.66 & 3 & 0.8707 & 7.22 \\
\hline August* & 0.70 & 3 & 0.8849 & 8.41 \\
\hline September & 0.71 & 3 & 0.8921 & 8.76 \\
\hline October & 0.72 & 3 & 0.8962 & 9.12 \\
\hline Mean & 0.695 & 3 & 0.8857 & 8.39 \\
\hline
\end{tabular}

*The average of PR in July and September is $0.70 \%$; ${ }^{*} \mathrm{p}=$ daily survival rate; equivalen with square root of proportion of female gravid. 
the longevity within the 4 month period ranged from 8 days to 10 days and might be the mosquitoes died because of insecticide residual spraying as a vectors control applied.

\section{Conclusion}

The longevity of An. sundaicus in coastal area Nongsa Pantai was below the minimum range for the completed life cycle and extrinsic incubation period (EIP).

\section{Author details}

${ }^{1}$ Department of Environmental Health, Faculty of Public Health, Universitas Indonesia, Kampus UI Depok, 16424, Indonesia. ${ }^{2}$ Department Biostatistic and Health Informatics, Faculty of Public Health, Universitas Indonesia, Kampus UI Depok, 16424, Indonesia.

Published: 15 October 2012

\section{References}

1. Smith DL, McKenzie FE: Statics and dynamics of malaria infection in Anopheles. Malaria Journal 2004, 3:13, doi:10.1186/1475-2875-3-13.

2. Davidson G: Estimation of the survival-rate of anopheline mosquitoes in nature. Nature 1954, 174(4434):792-793.

3. Zhou SS, Huang F, Wang JJ, et al: Geographical, meteorological and vectorial factors related to malaria re-emergence in Huang-Huai River of central China. Malar J 2010, 9:337, doi:10.1186/1475-2875-9-337.

4. Kiszewski A, Mellinger A, Spielman A, et al: A global index representing the stability of malaria transmission. Am J Trop Med Hyg 2004 70(5):486-498.

5. Zoller T, Naucke T, May J, et al: Malaria transmission in non-endemic areas: case report, review of the literature and implications for public health management. Malar J 2009, 8:71, 20.

doi:10.1186/1475-2875-11-S1-P93

Cite this article as: Susanna and Eryando: The longevity of Anopheles sundaicus in a small area: Nongsa Pantai Villages, Batam City, Indonesia. Malaria Journal 2012 11(Suppl 1):P93.

\section{Submit your next manuscript to BioMed Central and take full advantage of:}

- Convenient online submission

- Thorough peer review

- No space constraints or color figure charges

- Immediate publication on acceptance

- Inclusion in PubMed, CAS, Scopus and Google Scholar

- Research which is freely available for redistribution

Submit your manuscript at www.biomedcentral.com/submit
C Biomed Central 